\title{
Paving the way to achieving the United Nations Sustainable Development Goals for women from Indigenous communities: lessons from Attappady, India
}

\author{
Sarah T. Thomas ${ }^{1}$ - Elizabeth T. Thomas ${ }^{2} \cdot$ Michelle McLean $^{3} \cdot$ Thomas T. Titus $^{1,3}$
}

Received: 14 October 2020 / Accepted: 7 January 2021

(C) The Author(s) 2021 OPEN

\begin{abstract}
India is home to the world's second largest Indigenous population, comprising $8.6 \%$ of the national population. They are constitutionally recognised as 'Scheduled Tribes' to aid their development after centuries of oppression and sociocultural marginalisation through the caste system. Limited disaggregated data exist on India's Scheduled Tribe populations' health outcomes, including for Indigenous women. Kerala, one of India's southern states, is an intriguing case study. The State has outperformed other Indian states and South Asian countries with respect to a number of health and education indicators despite its more modest economic performance. Relatively little is known, however, about whether the State's tribal or 'Adivasi' population is prospering. This article used data from a cross-sectional observational study of tribal women conducted in the Attappady area in the Palakkad district in Kerala, South India, which has a dense tribal population. The outcomes for these communities were compared with the relevant United Nations 2030 Sustainable Development Goal (SDG) indicators as well as Kerala State data to identify areas of growth and need. The findings of this case study highlight successes as well as persisting gaps in health outcomes for women and children in marginalised tribal communities. Using a strengths-based approach, we propose possible strategies to address the perceived gaps.
\end{abstract}

\section{Introduction}

Globally, Indigenous peoples are disadvantaged, even in high income countries [1]. While standards of living and life expectancies have improved for most, Indigenous communities have not prospered like their non-Indigenous counterparts [2]. Historically, inequities have arisen as a result of their social, cultural and religious marginalisation and geographic isolation. These factors have impeded their access to quality health care, education and economic opportunities [3, 4]. In 2007, the United Nations Declaration on the Rights of Indigenous Peoples was adopted to protect the basic human rights and liberties of Indigenous Peoples as well as their right to self-determination and self-government [5].

Sustainability is a core philosophy shared by many Indigenous communities. They are custodians of centuries and in some cases, millennia of knowledge of the lands' biodiversity and environmental adaptation. Their profound respect for the land and nature is inextricably linked to their cultural and spiritual beliefs. Colonisation has endangered many Indigenous communities in the past few centuries. Globalisation has posed the most recent threat. Indigenous women, who are pivotal to the preservation of cultural heritage and transmission of traditional knowledge down the generations, have been disproportionately disadvantaged by globalisation, with changing sociocultural norms and dispossession

Elizabeth T. Thomas, elizabeth.thomas@phc.ox.ac.uk| ${ }^{1}$ Gold Coast University Hospital, 1 Hospital Boulevard, Southport, Gold Coast, QLD 4215, Australia. ${ }^{2}$ Centre for Evidence-Based Medicine, Nuffield Department of Primary Care Health Sciences, University of Oxford, Radcliffe Observatory Quarter, Oxford OX2 6HT, UK. ${ }^{3}$ Faculty of Health Sciences and Medicine, Bond University, 14 University Drive, Robina, Gold Coast, QLD 4226, Australia.

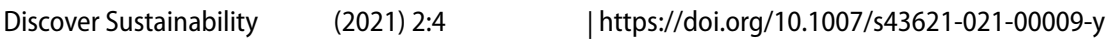


of land and natural resources. They have fallen particularly vulnerable to physical, emotional and sexual violence, drug and alcohol misuse, incarceration and discrimination both within and outside their communities [1]. Their limited health care access, educational opportunities, employment and participation in decision-making bodies further disenfranchise Indigenous women [6].

The United Nations 2030 Sustainable Development Goals (SDGs) codified in 2015, provide a comprehensive set of targets that seek 'to leave no one behind' and address inequities between population subgroups. Achieving gender equality is a key priority for the next decade which includes improving workforce participation and pay equality (SDG 1), nutrition and food quality (SDG 2), chronic disease and disability (SDG 3), universal access to sexual and reproductive health care in addition to maternal health and well-being (SDG 3), reducing female discrimination and violence (SDG 5), clean water and sanitation (SDG 6), improving living conditions (SDG 11) and political empowerment (SDG 16) [7]. There is criticism that insufficient consideration was given to the challenges facing Indigenous peoples in the SDGs as only two of the 169 SDG targets specifically mentioned Indigenous peoples [8]. Nevertheless, there is worldwide interest from governments, non-government organisations and Indigenous groups in complying with the SDG targets.

The focus on investing in women's health, education and empowerment appropriately reflects the evidence base showing benefits for children's survival and overall community well-being [9]. One systematic analysis reported that due to increased women's education in the sub-Saharan region, childhood mortality did not increase as a result of the HIV epidemic [10]. Drawing from this inference, a greater emphasis on improving the health and well-being of Indigenous women and their empowerment may be the key to 'closing the gap' and improving the prospects and survival of Indigenous communities overall.

This study examined the health status of women and children in the Indigenous tribal 'Adivasi' communities of Attappady in Kerala, India. Attappady, as a case study, attempts to highlight some of the successes as well as areas of need for women and children in marginalised communities. We offer possible strategies to address the identified needs.

\subsection{Understanding the study context}

India has the second largest population of Indigenous People-104.5 million (8.6\% of the population) belonging to 705 'Scheduled Tribes' protected under Article 342 of the Indian Constitution [11, 12]. According to the 2011 Indian Census data, Kerala, one of the southern Indian states, has a Scheduled Tribe population of 484,839, accounting for approximately $1.5 \%$ of the total population of Kerala (33.4 million) [11]. The majority of Kerala's Scheduled Tribes are found in the interior and hilly districts of Wayanad (31.2\%), Idukki (11.5\%) and Palakkad (10.1\%) [13]. Attappady, a region of the Palakkad district of Kerala nestled in the Silent Valley National Park and Nilgiri ranges of the Western Ghats, has a Scheduled Tribe population of 27,121 [13] with three distinct Scheduled Tribes-the Irular (77.6\%), the Mudugar (15.7\%) and the Kurumbar (6.7\%) tribes. Attappady has attracted negative media attention at a state and national level for its high infant mortality and malnutrition-related deaths $[14,15]$. In 2013, infant mortality in Attappady was more than fourfold that of the rest of Kerala [15].

Since 1974, the Kerala Government has made specific budget provisions for Scheduled Tribe development programmes. In 1976, the Attappady Integrated Tribal Development Project was the first of its kind to be established by the Government of Kerala to address specific tribal areas of need [13]. In 2015-2016, the equivalent of $\$ 56.3$ million USD were spent on educational programmes, housing schemes, treatment of tuberculosis, leprosy, scabies, sickle cell anaemia and water-borne diseases, to name a few initiatives [13].

Previous work in the field of Indian tribal health has highlighted the challenges of generating high quality data to monitor health outcomes for vulnerable tribal populations, with discrepancies between the data and reality in the field [16]. Previous community-based cross-sectional studies in other Indian tribal populations have been conducted to determine childhood immunisation rates [17], cervical cancer screening awareness [18] and maternal health service utilisation $[19,20]$. Across these studies, women's education was highlighted as one of the positive predictors of better maternal and child health outcomes [16-20].

Kerala has the highest level of women's education and literacy in the country and is one of two Indian states where females outnumber the number of males [13]. The State is not the wealthiest in terms of gross domestic product (GDP) per capita, so Kerala is an interesting case study in terms of how women's education and literacy is likely to be a significant factor in explaining why the State is outperforming other states across a range of health indicators. For example, Kerala has the highest life expectancies in India-74.9 years in Kerala compared with 67.9 years in India [21] —and the lowest infant mortality rate in the country which are comparable with those of middle-high income nations, surpassing 
the SDG target for 2020 [22]. There is, however, a paucity of disaggregated data pertaining to the health status of tribal communities in Kerala, including Attappady [23].

\subsection{Rationale for study location}

Attappady was chosen as the study setting because of the area's high density of Scheduled Tribe populations. The region has attracted national and state-level attention in media reports for high infant mortality and malnutrition rates. The State Government has made the region a priority for investment in health and social interventions. There are, however, scarce disaggregated health data for Attappady's tribal women and children which hinders effective social policy development. The present study sought to gather data on the general health and well-being of tribal women and their children in the Attappady region through a cross-sectional survey of tribal women as well as anecdotal experiences from non-government organisational workers and local primary health care providers. The findings highlight successes and potential areas for growth and investment to achieve the 2030 SDGs.

\section{Methods}

\subsection{Survey methodology}

A cross-sectional survey was conducted in 24 tribal hamlets from all three panchayats (tribal blocks) in the Attappady region between December 2014 and January 2015. Two hundred and sixty-two women aged 18 and over (legal age for consent) were recruited from the Irular, Mudugar and Kurumbar tribes and consented to participate in structured interviews. The outcome measures for the survey (Additional file 1: Appendix S1) were informed by the UN 2015 Millennium Development Goals targets prior to the publication of the 2030 SDGs [24]. India's National Family Health Survey (NFHS-4) 2015-2016 provided Kerala State data for comparison. The NFHS-4 survey was conducted in Kerala between March and October 2016 with over 11,000 women surveyed and a response rate of $98.3 \%$ [25]. The data were compared with the relevant SDG targets listed in Box 1. This study was approved by Bond University's Human Research Ethics Committee (RO 1909). The study was conducted in accordance with the Helsinki Declaration of 1975, as revised in 2000.

\subsection{Box 1-Relevant 2030 Sustainable Development Goals [7]}

\subsubsection{Target 2: End hunger, achieve food security and improved nutrition and promote sustainable agriculture}

2.1 By 2030, end hunger and ensure access by all people, in particular the poor and people in vulnerable situations, including infants, to safe, nutritious and sufficient food all year round.

2.2 By 2030 , end all forms of malnutrition, including achieving, by 2025 , the internationally agreed targets on stunting and wasting in children under 5 years of age, and address the nutritional needs of adolescent girls, pregnant and lactating women and older persons.

2.5 By 2030, maintain the genetic diversity of seeds, cultivated plants and farmed and domesticated animals and their related wild species, including through soundly managed and diversified seed and plant banks at the national, regional and international levels, and promote access to and fair and equitable sharing of benefits arising from the utilisation of genetic resources and associated traditional knowledge, as internationally agreed.

\subsubsection{Target 3: Ensure healthy lives and promote well-being for all at all ages}

3.1 By 2030, reduce the global maternal mortality ratio to less than 70 per 100,000 live births.

3.2 By 2030, end preventable deaths of newborns and children under 5 years of age, with all countries aiming to reduce neonatal mortality to at least as low as 12 per 1000 live births and under- 5 mortality to at least as low as 25 per 1000 live births. 
3.7 By 2030, ensure universal access to sexual and reproductive health-care services, including for family planning, information and education, and the integration of reproductive health into national strategies and programmes.

3.8 Achieve universal health coverage, including financial risk protection, access to quality essential healthcare services and access to safe, effective, quality and affordable essential medicines and vaccines for all.

2.2.3 Target 4: Ensure inclusive and equitable quality education and promote lifelong learning opportunities for all

4.1 By 2030, ensure that all girls and boys complete free, equitable and quality primary and secondary education leading to relevant and effective learning outcomes.

4.3 By 2030 , ensure equal access for all women and men to affordable and quality technical, vocational and tertiary education, including university.

4.4 By 2030, substantially increase the number of youth and adults who have relevant skills, including technical and vocational skills, for employment, decent jobs and entrepreneurship.

4.5 By 2030, eliminate gender disparities in education and ensure equal access to all levels of education and vocational training for the vulnerable, including persons with disabilities, indigenous peoples and children in vulnerable situations.

\subsubsection{Target 6: Ensure availability and sustainable management of water and sanitation for all}

6.1 By 2030, achieve universal and equitable access to safe and affordable drinking water for all.

6.2 By 2030, achieve access to adequate and equitable sanitation and hygiene for all and end open defecation, paying special attention to the needs of women and girls and those in vulnerable situations.

6.3 Support and strengthen the participation of local communities in improving water and sanitation management.

\subsubsection{Target 11: Make cities and human settlements inclusive, safe, resilient and sustainable}

11.1 By 2030, ensure access for all to adequate, safe and affordable housing and basic services and upgrade slums.

11.2 By 2030, provide access to safe, affordable, accessible and sustainable transport systems for all, improving road safety, notably by expanding public transport, with special attention to the needs of those in vulnerable situations, women, children, persons with disabilities and older persons.

\subsection{Statistical analysis}

Individual participant data were de-identified, coded and entered into IBM SPSS Statistics 24 software for analysis. Descriptive data were analysed by tribal groups. For dichotomous outcomes, the Chi-square test was used. The Pearson Chi-square test measured statistically significant differences in the proportions (\%) across the three tribes. For continuous variables, a normality test was conducted using quantile-quantile plots and the Shapiro-Wilks test. For normally distributed continuous data, a one-way independent measure analysis of variance (ANOVA) test was used to compare means and standard deviations. If the Shapiro-Wilks test was significant, implying data were not normally distributed, the non-parametric Kruskal-Wallis test was used to compare the medians of the three populations. Statistical significance was assumed if the $p$ value was $<0.05$.

\section{Results}

\subsection{Study populations}

Table 1 provides the baseline characteristics of the 262 women surveyed from the three tribes in terms of their marital status and education level. 
Table 1 Baseline characteristics of the 262 women surveyed from the three tribes in Attappady

\begin{tabular}{|c|c|c|c|c|c|c|}
\hline Baseline characteristics & Irular & Kurumbar & Mudugar & Statistical signficance & Test & Kerala data (\%) [25] \\
\hline Participants $(n)$ & 173 & 40 & 49 & & & $11033^{p .11}$ \\
\hline Mean age $( \pm S D)$ & $31 \pm 9.1$ & $27 \pm 6.7$ & $33 \pm 9.3$ & NSD & ANOVA & NA \\
\hline Response: $n(\%)$ & $172(99)$ & $40(100)$ & $49(100)$ & & & \\
\hline$\%$ married & 84.7 & 88.2 & 92.9 & NSD & $\chi^{2}$ & NA \\
\hline Response: $n(\%)$ & $171(99)$ & $40(100)$ & $49(100)$ & & & \\
\hline \multicolumn{7}{|l|}{ Education } \\
\hline \multicolumn{7}{|c|}{$\%$ women with no formal education by age category } \\
\hline $18-24$ years & $15.9^{\mathrm{ax}}$ & $46.7^{\mathrm{b}}$ & $18.2^{\mathrm{ax}}$ & $p=0.048^{\mathrm{ab}}$ & $\chi^{2}$ & \\
\hline $25-34$ years & $33.9^{x}$ & 38.9 & $22.2^{x}$ & NSD & $\chi^{2}$ & \\
\hline$\geq 35$ years & $63.5^{y}$ & 83.3 & $73.7^{y}$ & NSD & $\chi^{2}$ & \\
\hline Total & 40.7 & 48.7 & 41.7 & NSD & $\chi^{2}$ & $4.2^{\mathrm{p} .45}$ \\
\hline Response: $n(\%)$ & $167(97)$ & $39(98)$ & $48(98)$ & & & \\
\hline Between age-groups & $p<0.001^{x y}$ & NSD & $p=0.001^{x y}$ & & $\chi^{2}$ & \\
\hline \multicolumn{7}{|l|}{ Mean level of education (years $\pm S D$ ) } \\
\hline $18-24$ years & $10.2 \pm 2.6^{\mathrm{x}}$ & $10.3 \pm 2.4^{x}$ & $9.3 \pm 3.8$ & NSD & ANOVA & \\
\hline $25-34$ years & $8.3 \pm 3.0^{\text {ay }}$ & $6.3 \pm 2.6^{\text {by }}$ & $10.2 \pm 1.6^{c}$ & $p=0.002^{\mathrm{abc}}$ & ANOVA & \\
\hline$\geq 35$ years & $6.6 \pm 2.9^{\mathrm{az}}$ & $\dagger$ & $8.4 \pm 0.9^{b}$ & $p=0.021^{\mathrm{ab}}$ & ISTT" & \\
\hline Mean & $8.7 \pm 3.1$ & $8.2 \pm 3.2$ & $9.6 \pm 2.5$ & NSD & ANOVA & Median: $8.7^{\text {p.45 }}$ \\
\hline Response: $n(\%)$ & $97(92)$ & $20(95)$ & $28(97)$ & & & \\
\hline Between age-groups & $p<0.001^{x y z}$ & $p=0.003^{x y}$ & NSD & & & \\
\hline $\begin{array}{l}\text { \% women completed secondary } \\
\text { education or higher education }\end{array}$ & 18.4 & 12.5 & 14.3 & NSD & $\chi^{2}$ & 47.8 \\
\hline Response: $n(\%)$ & $166(95)$ & $39(98)$ & $48(98)$ & & & $([29]$, p. $67,[40])$ \\
\hline
\end{tabular}

Statistical tests: one-way analysis of variance (ANOVA), Pearson's Chi-square test $\left(\chi^{2}\right)$, Independent sample t-test (ISTT)

$N S D$ no significant difference

$p$ values indicated as NSD (no significant difference) suggest that the $p>0.05$

The letters a,b,c denote statistically significant differences in values across the three tribes

The letters $x, y, z$ denote statistically significant differences across age groups in the same tribe

${ }^{\dagger}$ Excluded from analysis as insufficient participants $-1=$ mean: 12.0

"Assuming non-equal variance

\subsection{Findings in relation to the relevant SDG goals and targets (Box 1)}

\subsubsection{SDG goal 2-end hunger, achieve food security and improved nutrition and promote sustainable agriculture}

Between 31 and $60 \%$ of women from all three tribes were at high risk of malnutrition (Table 2). Low household income, eating fewer than three meals a day and consumption of rice without supplementary micronutrient-rich vegetables were some of the reasons identified by the survey. Mass deforestation led to changes in the crops cultivated in the area, affecting the diversity and nutritional content of their diet. Their traditional diet previously comprised of millets, cereals, pulses, seasonal vegetables, wild edible plants, fish and small animal meat, but their land now predominantly cultivates bananas, sugar cane and other cash crops (SDG Target 2.5). Some women explained they would sell home-grown vegetables as a source of supplementary income. Iron deficiency was the leading cause of anaemia and the most widespread micronutrient deficiency followed by folic acid, iodine and vitamin A [26]. Iron deficiency anaemia is associated with increased maternal morbidity and mortality [27], as well as adversely impacting neonatal and infant growth, development, productivity and even childhood mortality [28].

\subsubsection{SDG targets 3.1 and 3.7-reproductive health}

3.2.2.1 Contraception The main form of contraception offered by medical outreach camps and health care facilities was tubal ligation as part of the State Government's family planning initiative (Table 3). The success of the family planning 
Table 2 Public health outcomes for the 262 women from the three Attappady tribes

\begin{tabular}{|c|c|c|c|c|c|c|}
\hline Public health outcomes & Irular & Kurumbar & Mudugar & $\begin{array}{l}\text { Statistical } \\
\text { significance }\end{array}$ & Test & $\begin{array}{l}\text { Kerala State } \\
\text { data }(\%) \\
{[25]}\end{array}$ \\
\hline Median duration (h) to primary health-care services & $0.5^{\mathrm{a}}$ & $6^{\mathrm{b}}$ & $2^{c}$ & $p<0.001$ & KW & NA \\
\hline Response: $n(\%)$ & $169(98)$ & $40(100)$ & $46(94)$ & & & \\
\hline$\%$ attending a health-care facility/camp in the past year & $73.8^{\mathrm{a}}$ & $90.0^{\mathrm{b}}$ & $89.6^{\mathrm{b}}$ & $p=0.011$ & $\chi^{2}$ & $42.1^{p .381}$ \\
\hline Response: $n(\%)$ & $164(95)$ & $40(100)$ & $48(98)$ & & & $\begin{array}{l}\text { (attended in } \\
\text { past } 3 \text { months) }\end{array}$ \\
\hline \multicolumn{7}{|l|}{ Malnutrition risk } \\
\hline$\%$ high risk of malnutrition (score $\geq 6$ ) & $56.1^{\mathrm{a}}$ & $60.0^{\mathrm{a}}$ & $30.6^{\mathrm{b}}$ & $p=0.001$ & $\chi^{2}$ & NA \\
\hline Response: $n(\%)$ & $245(94)$ & $40(100)$ & $49(100)$ & & & \\
\hline$\%$ anaemia (historic or current) & $39.4^{\mathrm{a}}$ & $61.5^{\mathrm{b}}$ & $63.2^{\mathrm{b}}$ & $p=0.032$ & $\chi^{2}$ & $34.3^{\text {p.337 }}$ \\
\hline Response: $n(\%)$ & $170(98)$ & $39(98)$ & $49(100)$ & & & \\
\hline \multicolumn{7}{|l|}{ Immunisation } \\
\hline$\%$ tetanus immunisation & 39.4 & 60.0 & 44.9 & NSD & $\chi^{2}$ & NA \\
\hline Response: $n(\%)$ & $170(98)$ & $40(100)$ & $49(100)$ & & & \\
\hline \multicolumn{7}{|l|}{ Clean water, sanitation and housing } \\
\hline \multicolumn{7}{|l|}{ Source of drinking water (\%) } \\
\hline River, streams & 50.0 & 34.3 & 30.6 & & $\chi^{2}$ & \\
\hline Pipe water, bore-well & 50.0 & 65.7 & 65.3 & NSD & & $94.3^{p .29}$ \\
\hline Others (pond) & 0 & 0 & 4.1 & & & \\
\hline Response: $n$ (\%) & $164(95)$ & $35(88)$ & $49(100)$ & & & \\
\hline$\%$ water boiled prior to consumption & $50.9^{\mathrm{a}}$ & $22.2^{\mathrm{b}}$ & $87.5^{c}$ & $p<0.001$ & $\chi^{2}$ & NA \\
\hline Response: $n(\%)$ & $169(98)$ & $36(90)$ & $48(98)$ & & & \\
\hline \multicolumn{7}{|l|}{ Most common bathing location } \\
\hline River & 67.7 & 77.5 & 72.9 & NSD & $\chi^{2}$ & NA \\
\hline Outdoor bathroom & 19.8 & 20.0 & 27.1 & NSD & & \\
\hline Home bathroom & $12.5^{\mathrm{a}}$ & $2.5^{\mathrm{b}}$ & $0^{\mathrm{b}}$ & $p=0.018$ & & \\
\hline Response: $n(\%)$ & $167(97)$ & $40(100)$ & $48(98)$ & & & \\
\hline$\%$ regular hand-washing & $86.2^{\mathrm{a}}$ & $100^{\mathrm{b}}$ & $100^{b}$ & $p=0.001$ & $\chi^{2}$ & NA \\
\hline Response: $n(\%)$ & $167(97)$ & $40(100)$ & $49(100)$ & & & \\
\hline$\%$ access to latrine & $21.7^{\mathrm{a}}$ & $5.0^{\mathrm{b}}$ & $8.2^{\mathrm{b}}$ & $p=0.008$ & $\chi^{2}$ & $99.2^{p .29}$ \\
\hline Response: $n(\%)$ & $166(96)$ & $40(100)$ & $49(100)$ & & & \\
\hline$\%$ living in $23 \mathrm{~m}^{2}$ squared dwellings with $\geq 5$ occupants & $42.2^{\mathrm{a}}$ & $70.0^{\mathrm{b}}$ & $45.8^{\mathrm{a}}$ & $p=0.006$ & $\chi^{2}$ & NA \\
\hline Response: $n$ (\%) & $166(96)$ & $40(100)$ & $48(98)$ & & & \\
\hline$\%$ barefoot outdoors & $48.1^{\mathrm{a}}$ & $37.1^{\mathrm{ab}}$ & $21.3^{b}$ & $p=0.004$ & $\chi^{2}$ & NA \\
\hline Response: $n(\%)$ & $160(93)$ & $35(88)$ & $47(96)$ & & & \\
\hline
\end{tabular}

Statistical tests: Kruskal Wallis test (KW), Pearson's Chi-square test $\left(\chi^{2}\right)$

The letters a,b,c denote statistically significant differences in values across the three tribes

NSD no significant difference

$p$ values indicated as NSD suggest that the $p>0.05$ (no significant difference)

initiative was evidenced by the rate of sterilisation-between 47 and 63\% compared with the State average of $36 \%$. Most women had two or three children and the State's average fertility rate was 1.6 [25].

3.2.2.2 Ante-natal care A lower proportion of tribal women (63 to 80\%) reported attending at least one ante-natal visit compared with the State average of $92.6 \%$ (Table 3) [25, 29]. The World Health Organization's standards of ante-natal care have changed, stipulating that pregnant women must attend at least eight ante-natal visits compared with the previous recommendation of four ante-natal visits, which would be a challenging benchmark for ante-natal care delivery in Attappady [30]. The issues listed including (1) distance to obstetric facility, (2) frequency of ante-natal care visits, (3) rate 
Table 3 Maternal health outcomes for the 262 women across the three Attappady tribes

\begin{tabular}{|c|c|c|c|c|c|c|}
\hline Women's maternal and reproductive health indicators & Irular & Kurumbar & Mudugar & $\begin{array}{l}\text { Statistical } \\
\text { signifi- } \\
\text { cance }\end{array}$ & Test & $\begin{array}{l}\text { Kerala state } \\
\text { data (\%) } \\
{[25]}\end{array}$ \\
\hline Total fertility rate (mean number of children \pm SD) & $1.9 \pm 1.4^{\mathrm{a}}$ & $2.4 \pm 1.5^{\mathrm{ab}}$ & $2.4 \pm 1.3^{b}$ & $p=0.034$ & ANOVA & $1.6^{\mathrm{p} .109}$ \\
\hline Response: $n(\%)$ & $138(80)$ & $34(85)$ & $45(92)$ & & & \\
\hline$\%$ never conceived & 21 & 15 & 9 & NSD & $\chi^{2}$ & NA \\
\hline Mean age at first pregnancy $( \pm S D)$ & $18.7 \pm 3.2$ & $18.8 \pm 3.1$ & $19.5 \pm 3.3$ & NSD & ANOVA & NA \\
\hline Response: $n(\%)$ & $155(90)$ & $36(90)$ & $43(88)$ & & & \\
\hline$\%$ first pregnant under age 20 & 47 & 56 & 55 & NSD & $\chi^{2}$ & $3.0^{\mathrm{p} .100}$ \\
\hline Response: $n(\%)$ & $155(90)$ & $34(88)$ & $38(84)$ & & & \\
\hline \multicolumn{7}{|l|}{ Ante-natal care } \\
\hline Proportion of women who attended at least one ante-natal care visit & 63 & 74 & 80 & NSD & $\chi^{2}$ & $92.6^{\text {p.216 }}$ \\
\hline Response: $n(\%)$ & $136(99)$ & $34(100)$ & $43(96)$ & & & \\
\hline Complications at pregnancy or birth & 20 & 16 & 27 & NSD & $\chi^{2}$ & NA \\
\hline Response: $n(\%)$ & $133(97)$ & $32(94)$ & $44(98)$ & & & \\
\hline \multicolumn{7}{|l|}{ Births } \\
\hline Births $(n)$ & 329 & 91 & 119 & & & \\
\hline$\%$ births by Caesarean section & 7.4 & 2.2 & 10.7 & NSD & $\chi^{2}$ & $35.8^{p .248}$ \\
\hline $\begin{array}{l}\% \text { births in a health facility or with skilled birth attendants (mid- } \\
\text { wives/medical officers) present }\end{array}$ & 47 & 43 & 56 & NSD & $\chi^{2}$ & $99.9^{p .248}$ \\
\hline Response: $n$ women (\%) & $136(99)$ & $34(100)$ & $43(96)$ & & & \\
\hline \multicolumn{7}{|l|}{ Contraception } \\
\hline$\%$ female sterilisation (tubal ligation) & 47 & 48 & 63 & NSD & $\chi^{2}$ & $45.8 \Sigma^{p .123}$ \\
\hline Response: $n(\%)$ & $159(92)$ & $40(100)$ & $48(98)$ & & & $53.3 \partial^{p .123}$ \\
\hline
\end{tabular}

The letters $a$ and $b$ denote statistically significant differences in values across the three tribes

$\partial$ any method of contraception used

$\Sigma$ female sterilisation rate (tubal ligation)

Statistical tests: one-way analysis of variance (ANOVA), Pearson's Chi-square test $\left(\chi^{2}\right)$

of home births with no skilled birth attendants and (4) limited understanding of the importance of maternal nutrition and supplement intake, all provide an overall indication of maternal health in the Attappady tribal population. Although this study did not ascertain maternal mortality rates in the region, addressing these issues could improve maternal outcomes and mortality rates among tribal women in Attappady (SDG Target 3.1).

3.2.2.3 Peri-natal care Between 43 and $56 \%$ of tribal women gave birth in a heath facility. Home births in the absence of a skilled birth attendant was common (Table 3). This correlates with lower rates of obstetric intervention as only 2 to $11 \%$ of women underwent Caesarean section, which was much lower than the rest of the State (36\%) [25]. Various Obstetrics and Gynaecology Societies are divided about the safety of planned home births and health facility births with skilled birth attendants. The absence of skilled birth attendants does, however, increase the risk of life-threatening obstetric and neonatal complications such as post-partum haemorrhage, puerperal infections, obstructed labour and foetal distress, leading to maternal and neonatal mortality [31]. According to the United Nations Population Fund estimates, a skilled birth attendant can reduce two-thirds of all maternal and newborn deaths [32]. The WHO recommends that every birth is attended by a skilled birth attendant who is equipped to manage the potential complications of childbirth, but this is a challenge for many women in lower resource settings [33].

\subsubsection{SDG target 3.2-child health}

Another area of success was the high uptake of childhood immunisations in tribal children, with a large proportion (78-94\%) of women reporting their children had received all the age-recommended immunisations. This is comparable with the Kerala State average of $82 \%$ (Table 4) $[25,34]$. Immunisations were provided by mobile medical units or hospital clinics. 
Table 4 Child health outcomes for the 262 women across the three Attappady tribes

\begin{tabular}{|c|c|c|c|c|c|c|}
\hline Child health indicators & Irular & Kurumbar & Mudugar & $\begin{array}{l}\text { Statistical } \\
\text { signifi- } \\
\text { cance }\end{array}$ & Test & $\begin{array}{l}\text { Kerala state } \\
\text { data (\%) } \\
{[34]}\end{array}$ \\
\hline$\%$ age-recommended immunisation & $78.2^{\mathrm{a}}$ & $93.9^{\mathrm{b}}$ & $93.2^{\mathrm{b}}$ & $p=0.015$ & $\chi^{2}$ & $82.1^{p .269}$ \\
\hline Response: $n(\%)$ & $133(77)$ & $33(83)$ & $44(90)$ & & & \\
\hline$\%$ neonatal medical checks & 58 & 67 & 67 & NSD & $\chi^{2}$ & $49.1^{\mathrm{p} .248}$ \\
\hline Response: $n(\%)$ & $133(77)$ & $33(83)$ & $42(86)$ & & & \\
\hline Mean birth weight $(B W)(\mathrm{kg} \pm \mathrm{SD})$ & $2.6 \pm 0.5$ & $2.4 \pm 0.4$ & $2.6 \pm 0.7$ & NSD & ANOVA & $N A^{*}$ \\
\hline$n$ births (\%) with birth weights & $151(46)$ & $30(33)$ & $54(45)$ & & & \\
\hline
\end{tabular}

The letters $a$ and $b$ denote statistically significant differences in values across the three tribes

${ }^{*} 15.5 \%$ Kerala women reported their child(ren) had birth weights $<2.5 \mathrm{~kg}$ ([29], p. 264)

Statistical tests: one-way analysis of variance (ANOVA), Pearson's Chi-square test $\left(\chi^{2}\right)$

\begin{tabular}{lcll}
\hline Deaths & $\begin{array}{l}\text { Attappady total } \\
\text { (total) }\end{array}$ & $\begin{array}{l}\text { Attappady tribes (per 1000 } \\
\text { live births) }\end{array}$ & $\begin{array}{l}\text { Kerala state (per } \\
1000 \text { live births) }\end{array}$ \\
\hline Infants & 15 & 28 & $10[35]$ \\
Children $<5$ years & 20 & 37 & $12[36]$ \\
Live births across all tribes & 539 & & \\
\hline
\end{tabular}

Table 5 Infant and child mortality across the total number of live births across the three Attappady tribes

The average birth weight was reported to be $2.4-2.6 \mathrm{~kg}$ across the three tribes, whereas only $15 \%$ of Kerala women reported their child(ren) weighed $2.5 \mathrm{~kg}$ or less at birth. Thus, it can be inferred that more than half of all children in Attappady were born underweight by Indian standards. The high infant mortality in the Attappady region attracted significant media attention $[14,15]$, with considerable numbers of neonates having low birth weights and dying from malnutrition.

It was difficult to reliably estimate infant mortality in the area as the numbers were self-reported by women, some of whom had first given birth more than two decades ago. Our estimates (infant mortality of 28 deaths per 1000 live births and child mortality of 37 deaths per 1000 live births) could be an under- or over-estimation of the problem and would require access to birth, hospital or childhood records for a more reliable result (even though half of the births were in a health care facility) (Table 5). For 2015, Kerala's infant mortality rate was estimated to be 10 deaths per 1000 live births in 2016, with child mortality (under 5) recorded as 12 deaths per 1000 live births [35, 36]. The SDGs calls for infant mortality to be reduced worldwide to less than 12 per 1000 live births and childhood mortality below 25 per 1000 live births [7]. Kerala is the only State among the bigger Indian States to have achieved these SDG targets, when the national infant mortality rates is 34 deaths per 1000 live births, and the under-five mortality is 48 deaths per 1000 live births [35, 36]. Scheduled Tribes from rural populations like the three tribes in Attappady had an infant mortality rate of 47 deaths per 1000 live births and under-five mortality rate of 57 deaths per 1000 live births [35]. Making comparisons between this study's findings and State or National data is not advisable given this study's methodology.

\subsubsection{SDG target 3.8, 11.2-access to health care}

Kurumbar women had significantly longer travel times to the nearest health care facility $(p=0.00)$ compared with the other tribes, due to poor road conditions, difficult terrain and unreliable transport particularly at night (Table 2). In the monsoon season, access to health care was even more challenging. A mobile medical unit with a travelling doctor and nurses set up medical camps in remote communities on a monthly basis. The result that more Kurumbar and Mudugar women (Table 2) reported some form of health care contact compared with Irular women could indicate the success of these medical camps. 


\subsubsection{SDG goal 4-education}

Rates of education demonstrated a promising trend, as younger tribal women were more likely to be educated and complete more years of schooling (year 9-10), compared with older women (Table 1). This suggested increasing levels of education for younger generations. Overall, 12 to $18 \%$ of tribal women pursued higher education compared with $48 \%$ of Kerala women. As the local boarding school in Agali (town centre of Attappady) does not offer education above Standard 10, girls (and boys) had to travel or board in a secondary school in the nearest cities of Palakkad, Thrissur, Cochin or Coimbatore which are 60,103, 192 and $58 \mathrm{~km}$ away, for further education. Anecdotally, pursuing higher education in these communities did not appear to be a significant priority as employed women predominantly worked in agriculture which does not require higher qualifications. Interestingly, in spite of Kerala's growing enrolment of women in higher education (with 59\% of students enrolled in university between 2014 and 2015) [36], female employment has fallen in recent years $[29,37]$. This might explain the higher incidence of pregnancies in tribal women under 20 years of age, as fewer employment opportunities in remote communities may result in earlier childbearing. It was also suggested from anecdotal experience that "the lack of sanitary facilities in schools for adolescent girls were a major factor in retention of girls at school. Local NGOs attempted to construct special rooms which contained such facilities in both schools and hostels though it was unknown whether there was uptake of these facilities or whether this translated into increased school retention rates for adolescent girls. The conventional tribal mindset was to keep girls at home once they reach puberty and begin the process of looking for prospective grooms"."

\subsubsection{SDG goal 6-access to clean water and sanitation}

Access to clean water and sanitation facilities appears to be an area of need in the Attappady region when comparing State data and the SDG Target 6 (Table 2). One-third to half of all women reported their primary source of drinking water to be a river or stream and only one-fifth of women in one tribe consistently boiled water before drinking (Table 2). An NGO worker cited that "a small proportion of Mudugar tribal people had access to collect firewood for fuel though they were aware of the need to boil water" (see footnote 1). Therefore in these cases, lack of firewood was the main reason for not always boiling water. Kurumbar women who had access to firewood were, however, not consistently aware of the importance of boiling water (see footnote 1).

Safe drinking water should be accessible to all communities by 2030 (SDG Target 6.1) which may involve infrastructural investment. With access to household latrines (5-22\%) considerably lower than the $99.2 \%$ State average [25, 29], open defaecation was common practice in all three communities (Table 2). This would increase the risk of diarrhoea, dysentery and spread of diseases such as viral, bacterial and parasitic infestations via faecal-oral transmission [38]. Further, walking barefoot outdoors on contaminated soil is the primary mode of transmission for parasitic infections as larvae penetrate the skin [38]. The practice of open defaecation is also linked to increased risk of physical and sexual violence against women, with one nation-wide Indian study reporting that women who practise open defaecation are twice as likely to experience non-partner sexual violence compared with women who had a household toilet [39].

\subsubsection{SDG goal 11—creating safe, resilient and sustainable living settlements}

Across the three tribes, $42-70 \%$ of women reported staying in overcrowded living conditions (Table 2). Most houses were small cement $250 \mathrm{ft}^{2}$ (approximately $23 \mathrm{~m}^{2}$ ) dwellings with two or three rooms (common area, bedroom and/or kitchen). These houses were constructed in the 1970s by the Kerala Government as part of the laksham veedu (translated to one lakh) Housing Scheme for landless agricultural labour households [13,40]. We defined overcrowding as five or more individuals living in a $23 \mathrm{~m}^{2}$ dwelling based on the UN definition of overcrowding as more than one-person/5 $\mathrm{m}^{2}$ floor area [41, 42]. Overcrowding increases the risk of disease transmission, particularly respiratory illnesses such as active tuberculosis which has previously been reported as prevalent in this area [40]. Many of these dwellings were poorly maintained with farm animals freely roaming through the villages and homes. Other houses were made of organic material including bamboo, mud and straw.

\footnotetext{
1 Personal communication with Dr. Elizabeth Zachariah-NGO representative.
} 


\section{Discussion: possible strategies for achieving the SDGs}

\subsection{Leadership and the rights of tribal women}

The Government of Kerala has made promising strides to establish schemes investing in the health and education of young girls $[43,44]$. These well-motivated initiatives cannot, however, be assessed effectively if there are no data that specifically measure outcomes pre- and post-intervention. Government intervention will be neither effective nor sustainable if members of the local community are not involved. There should be a prioritised effort to involve community representatives in policy-making at a grassroots level and in a state-wide, national and international context. Indigenous leaders should be active participants in establishing their own development indicators, developing solutions and monitoring progress towards achieving these indicators. Sustainability has been a major concern in communities where previous government interventions have not been successfully adopted. In Attappady, interventions with a once-off point of contact, such as childhood immunisation and sterilisation, had greater rates of success than sustained interventions that require prolonged immersion and follow-up such as ante-natal care.

Indigenous women should be encouraged to play an active role in decision-making for local community needs. This needs to be done in a culturally sensitive manner, especially in settings where there are perceived gender roles in society and hierarchies. Female Indigenous spokespeople play a particularly important role when it comes to matters of "women's business".

The SDGs provide measurable targets for nations around the world to achieve, which highlight areas of success or need for social intervention. Emphasising statistical disparities between a vulnerable group and the rest of the population can, however, contribute to a 'deficit-discourse' in which the outcomes of Indigenous tribal communities are viewed through the conventional Western lens [45]. Instead, we advocate a strengths-based approach which has been adopted in the Australian Aboriginal and Torres Strait Islander literature $[45,46]$. This requires governments, health care researchers and workers and policy-makers to work in partnership with communities and individuals to draw on their strengths such as their traditional knowledge to improve outcomes.

It is essential to respect cultural values and religious beliefs, and better understand Indigenous people's attachment to the land and ancestral territories. There is important knowledge to be gained from Indigenous communities about developing sustainable solutions to improve agricultural practices, especially since these communities are disproportionately endangered by the consequences of global warming, including loss of land and local resources, livelihoods, local biodiversity and worsening inequity [47].

\subsection{Improved maternal and child health}

The SDG targets stipulate that maternal mortality rates should be below 70 deaths per 100,000 women. In Attappady, it is common belief among the tribal people that childbirth is a natural process which does not require intervention. High-risk women should, however, be encouraged to access health facilities for ante-natal care and delivery care where a skilled attendant is present.

Where there is a shortage of skilled birth attendants, there may be a role for up-skilling and integrating community health workers and traditional birth attendants to provide maternity and newborn services. The success of this strategy is context-specific and may provide a partial solution [48]. Language and cultural issues present a clear barrier to adequate health care. It is vital that health care teams can care for tribal women in a respectful, inclusive manner. Ideally, care should be delivered by trained individuals who hail from their own communities or with interpreters, so that women do not feel alienated or inferior. Cultural sensitivity training for external health care workers may assist in providing respectful care.

There is some evidence for implementing schemes that offer financial incentives to improve maternal outcomes [49]. In Attappady, the Scheduled Tribes Development Department division of the State Government has an initiative called "Janani-JanmaRaksha" which provides financial assistance of 1000 rupees per month to women from the third month of pregnancy to the completion of the child's first year of life [43]. In Orissa, India, two programmes-a conditional cash transfer programme (the JSY) and Mamata-were established by the Government to offer partial wage compensation for women to receive ante-natal care, deliver in health facilities, improve antenatal and infant nutrition, post-natal care and immunisation [50]. To address access, one potential solution is to establish maternity shelters that encourage pregnant 
women to stay there towards the end of their pregnancies. These maternity homes were implemented in Eritrea in 2007, leading to a $56 \%$ increase in facility deliveries and no maternal deaths in the 20 months following its introduction [51].

Attappady can be considered a success in terms of the high uptake of female sterilisation as a method of contraception. This method could be implemented in other regions as it is a one-off intervention with proven efficacy. Sexual health education and awareness for men and women regarding other methods of contraception including barrier contraception is required in reducing rates of sexually transmitted infections (STIs). Prevalence of STIs are not estimated in this study. A United Nations report on worldwide Indigenous groups found that there are high rates of sexually transmitted infections in several Asian countries including Thailand, Myanmar, India, Nepal and Indonesia [52].

\subsection{Improved food security}

The tribal relationship to the land and local biodiversity affects their livelihood as well as nutrition. Loss of land and displacement of marginalised groups can result in loss of control over their resources, including land and natural resources [1]. With mass deforestation and change in biodiversity, the tribal diet has become impoverished of nutritious content which is particularly problematic for pregnant women and children. The evidence supporting mandatory food fortification is equivocal with respect to improving the nutritional status of whole communities [53, 54]. Lately, Attappady's local government has overseen the revival of an old tribal tradition "Ooraduppu" or Hamlet Hearth with 192 community kitchens set up to cater food for more than 13,000 tribal people and special kitchens for pregnant women [53]. The State Government has also invested 68 million rupees in 2017 into a Millet Village scheme to reinvigorate the local production of traditional varieties of millets, pulses and other cereals to improve food security in the area, agricultural economy and nutrition of tribal communities [55]. It is yet to be seen whether these initiatives will increase the community's access to nutritious food and reduce malnutrition, especially in vulnerable groups (SDG Targets 2.1, 2.2).

\subsection{Improved sanitation}

Water safety can be a major concern in tribal communities where there is widespread transmission of diarrhoeal illnesses. Though water boiling and treatment would be necessary for surface water sources (lakes, rivers), this would require further use of firewood which may be a scarce resource. Other alternatives may include improved water sources, such as groundwater. Alternatively, rainwater harvesting technology can be employed. This technology would not only guarantee water supply, but it can be used to grow and sell local produce as a source of household income [56].

Open defaecation practices needs to be eliminated (SDG Target 6.2) by building sanitation facilities and adequate waste disposal systems (SDG Target 6.6). Equally, it is vital to increase hygiene awareness to target behavioural change. In order to meet sustainability criteria, a sanitation system has to be cost-effective, socially and culturally acceptable, and aim to protect the environment. From a hygiene standpoint, they should reduce the risk of exposure to harmful bacteria at every step of the sanitation system chain, from the latrine, to the collection, treatment system, disposal and downstream populations. Poorly maintained sanitation facilities can harbour disease and worsen outcomes for these communities.

There should be methods for safe disposal and/or recycling of waste and by-products. The conversion of waste into biomass fuel as a renewable form of energy provides one example of a sustainable solution. The entire sanitation system should ideally be able to be built, operated and maintained by local communities, reducing their dependence on external stakeholders. Sanitation systems should be robust and adaptable when faced with additional risks such as water shortage or flooding. From an economic standpoint, communities should benefit from running sanitation and wastewater systems by earning income from operation and maintenance, and indirectly from increased agricultural yield if refuse is converted into organic fertiliser.

It is not an infrequent occurrence where well-meaning groups and NGOs arrive in local Indigenous communities to install clean water and sanitation facilities and build housing. It is evident that without close community partnership, initiatives are destined to fail. There is no one-size-fits-all approach when it comes to solutions for clean water and sanitation systems. There needs to be local partnership with community leaders from each hamlet in the design and maintenance of infrastructure for these interventions to be sustainable and have long-term benefit. 


\subsection{Education}

Health literacy and education is essential to improving women's health and wellbeing. The State Government has offered scholarships and subsidies that incentivise girls and young women to seek secondary and tertiary education. Vocational training schemes are equally important for girls who do not plan to pursue more traditional professional courses. There are two promising new initiatives announced by the State Government. The Gothrabandhu Scheme aims to engage tribal teachers in primary schools and the Gothra Valsalyanidhi scheme which is an endowment for tribal girl children born after April 2017 to ensure they are registered at birth, immunised and educated to a minimum level of Standard 10. The endowment can be extended to paying for higher education [44]. The effectiveness of these schemes have yet to be evaluated.

The educational content of primary and secondary education also needs closer scrutiny (SDG Target 4.1). The curriculum needs to include knowledge of local tribal culture and customs and encourage young girls to understand their own cultural beliefs, practices and share this knowledge. Practical life skills need to be honed (e.g. entrepreneurship, administrative, collaborative, problem-solving skills). Empowered, self-determined tribal women can improve their own financial prospects and wellbeing along with their communities (SDG Target 4.4) [57]. Improving health literacy and inculcating positive health-seeking behaviours that improve health status (i.e. hand-washing, boiling drinking water and wearing closed footwear outdoors) should be integrated into the curriculum [56]. Vocational training in priority areas identified by the community (e.g. agriculture, education, health-care, construction, etc.) could be offered beyond schooling and segue into employment in the community (SDG Targets 4.3 and 4.5 ).

\subsection{Health care access}

The UN reported that in some Asian countries, due to the remote location of Indigenous Peoples and lack of government response to improving health infrastructure, the majority of these communities rely on traditional medicines [58]. One potential strategy to improve access is medical outreach camps with travelling doctors and nurses that visit remote communities. More Kurumbar and Mudugar women reported some form of health care contact in spite of longer travel distances compared with Irular women. This indicates the potential success of medical outreach camps. However, emergency care is not readily available and health care access is particularly difficult for remote communities and almost impossible in monsoon seasons. A Hindu Times news article reported how a Kurumbar family carried a pregnant woman in labour on a makeshift stretcher for seven kilometres through dense forests and streams to the nearest healthcare facility [59]. Many women in remote hamlets reported difficulty accessing a health care facility if they needed it. Better infrastructure including roads and transportation are required to bridge the gap in health care access.

Affordability also presents a major access issue for Indigenous and tribal women. In Nepal, $43 \%$ of Indigenous women reported being unable to access health care services due to cost. The poverty gap in most Asian counties appears to be widening and threatens to worsen health care access for Indigenous women [60].

Health care facilities are also often understaffed and the health workforce is transient. When staff are not accustomed to the cultural norms of the population, there can be mistrust of health care providers. In Attappady, one of the women from the Mudugar tribes completed her medical degree and returned to Attappady as a doctor along with her husband who became the district medical officer. ${ }^{2}$ There should be a targeted effort to provide incentives for young men and women to pursue these career pathways. Women from tribal communities can be actively recruited to health care teams as nurses and local health care workers. Indigenous representation in health care will improve access to health care for tribal communities.

\subsection{Study limitations and recommendations for future research}

With a small study sample size, there is risk of sampling error. Consecutive sampling can introduce volunteer bias if healthier individuals are more willing to participate and have had better health outcomes than those who did not participate in our study. The self-reporting nature of this study introduces recall bias. Further research is needed with robust disaggregated data for different tribal communities. The importance of collecting disaggregated data cannot be underestimated. Providing averages for large groups mask discrepancies in health outcomes in vulnerable population

\footnotetext{
2 Personal communication with Dr. Prabhu Das_District Medical Officer of Attappady.
} 
sub-groups. Dissemination and transparent reporting of disaggregated data would highlight where disparities exist and drive more effective social policies and investments [61]. Research is also required to (1) better understand traditional knowledge systems, (2) evaluate the sustainability and efficacy of existing social and health interventions such as mobile clinics and, (3) identify areas where employable skills may lie (midwives, health workers or teachers) to increase their workforce capacity. Understanding how Kerala addresses the inequities affecting tribal populations health can confer benefits to researchers and policy-makers worldwide.

\section{Conclusion}

Attappady's tribal communities are making progress towards the 2030 SDGs with promising initiatives that demonstrate a shift in the Government's focus on sustainable development. In Attappady, areas that require ongoing attention include girls' education, health literacy, sanitation and addressing barriers to accessing health care, especially ante-natal care. Robust data need to be collected to highlight where health gaps exist for Indigenous peoples, not only in Kerala, but also globally. Women are likely to be the key to improving the overall health and well-being of their communities. Sustainable and effective community development requires a strengths-based approach with sensitivity to local tribal cultures and systems and emphasis on education, participation, empowerment and partnership with Indigenous women.

Supplementary Information The online version contains supplementary material available at https://doi.org/10.1007/s43621-021-00009-y.

Acknowledgements The authors would like to acknowledge the muppans and the women of Attappady for their participation in the survey which served to highlight their community's needs. We thank the following contributors: Dr. Sara Titus (assistance with data collection in Attappady); Father James Morais, Director of the Attappady Adivasi Development Initiative (AADI) (for providing local insight and support in arranging interpreters and drivers); Florence, Murukesh and Muthu (the local tribal interpreter and guides); Mr. and Mrs. K. K. Koshy from Bethany Bala Bhavan (for hosting us during our stay), and, finally, Dr. Elizabeth Zachariah (for inspiring this project and the numerous discussions that were had).

Authors' contributions Conceptualisation: STT, ETT, TTT; methodology: STT, ETT, MM, TTT; formal analysis: STT; investigation: STT, ETT; writing —original draft preparation: STT, ETT; writing —reviewing and editing: STT, ETT, MM, TTT; supervision: TTT. All authors read and approved the final manuscript.

Funding The authors did not receive any specific grant from funding agencies in the public, commercial, or not-for-profit sectors for the submitted work.

Data availability All data generated or analysed during this study are included in this published article.

Ethics approval and consent to participate This study was approved by Bond University's Human Research Ethics Committee (RO 1909). The study was conducted in accordance with the Helsinki Declaration of 1975, as revised in 2000.

Competing interests The authors have no relevant financial or non-financial interests to disclose.

Informed consent Written consent was obtained from willing participants. Verbal consent was obtained where participants could not write or would only sign government documentation.

Open Access This article is licensed under a Creative Commons Attribution 4.0 International License, which permits use, sharing, adaptation, distribution and reproduction in any medium or format, as long as you give appropriate credit to the original author(s) and the source, provide a link to the Creative Commons licence, and indicate if changes were made. The images or other third party material in this article are included in the article's Creative Commons licence, unless indicated otherwise in a credit line to the material. If material is not included in the article's Creative Commons licence and your intended use is not permitted by statutory regulation or exceeds the permitted use, you will need to obtain permission directly from the copyright holder. To view a copy of this licence, visit http://creativecommons.org/licenses/by/4.0/.

\section{References}

1. United Nations Department of Economic and Social Affairs. 1's indigenous peoples. New York: United Nations Publications; 2015.

2. Office of the Registrar General \& Census Commissioner, India. Primary census abstract data for scheduled tribes (ST) (India \& States/ UTs_District Level). 2011. www.censusindia.gov.in/2011census/population_enumeration.html. Accessed 3 Apr 2019.

3. Gracey M, King M. Indigenous health part 1: determinants and disease patterns. Lancet. 2009;374(9683):65-75.

4. King M, Smith A, Gracey M. Indigenous health part 2: the underlying causes of the health gap. Lancet. 2009;374(9683):76-85.

5. United Nations. United nations declaration on the rights of indigenous peoples. 2008. https://www.un.org/esa/socdev/unpfii/docum ents/DRIPS_en.pdf. Accessed 30 Nov 2020. 
6. United Nations Office of the Special Adviser on Gender Issues and Advancement of Women and the Secretariat of the United Nations Permanent Forum on Indigenous Issues. Gender and indigenous peoples: overview. New York: United Nations Department of Economic and Social Affairs, United Nations; 2010. https://www.un.org/esa/socdev/unpfii/documents/Briefing\%20Notes\%20Gender\%20and\%20lnd igenous\%20Women.pdf. Accessed 3 Apr 2019.

7. United Nations. Sustainable development goals. United Nations. https://www.un.org/sustainabledevelopment/sustainable-developmen t-goals/. Accessed 3 Apr 2019.

8. Martinez JDO, Lizama AS. Indigenous peoples and indigenous women in the sustainable development goals. In: Seth N, Barrado CMD, Lalaguna PD, editors. SDGs, main contributions and challenges. New York: United Nations Institute for Training and Research (UNITAR); 2019. p. 71-91.

9. Cleland J. The benefits of educating women. Lancet. 2010;376(9745):933-4.

10. Gakidou E, Cowling K, Lozano R, Murray CJ. Increased educational attainment and its effect on child mortality in 175 countries between 1970 and 2009: a systematic analysis. Lancet. 2010;376(9745):959-74.

11. Office of the Registrar General \& Census Commissioner, India. Primary census abstract data for scheduled tribes (ST) (India \& States/ UTs_District Level). 2011.www.censusindia.gov.in/2011census/population_enumeration.html. Accessed 8 July 2019.

12. Lama M. Access to health services by indigenous peoples in Asia. State of the world's indigenous peoples: indigenous peoples' access to health services. New York: United Nations; 2016. p. 33-57.

13. Board KSP. Economic review 2016 (Volume 1). Thiruvananthapuram: Government of Kerala; 2017.

14. Prabhakaran G. Malnutrition claims five lives in Attappady. In:The Hindu. 2013. https://www.thehindu.com/news/national/kerala/malnu trition-claims-five-lives-in-attappady/article4592083.ece. Accessed 14 Apr 2019.

15. Manikandan A. A Tragedy unfolding: tribal children dying in Attappady. 2014. https://www.epw.in/node/128891/pdf.Accessed 1 Apr 2019

16. Dehury RK, Chatterjee SC. Assessment of health management information system for monitoring of maternal health in Jaleswar Block of Balasore District, Odisha, India. Indian J Public Health. 2018;62(4):259-64.

17. Dhadwal D, Sood R, Gupta AK, Ahluwalia SK, Vatsayan A, Sharma R. Immunization coverage among urban and rural children in the Shimla hills. J Commun Dis. 1997;29(2):127-30.

18. Ghosh S, Mallya SD, Shetty RS, Pattanshetty SM, Pandey D, Kabekkodu SP, et al. Knowledge, attitude and practices towards cervical cancer and its screening among women from tribal population: a community-based study from Southern India. J Racial Ethn Health Disparities. 2020. https://doi.org/10.1007/s40615-020-00760-4.

19. Jat TR, Ng N, San SM. Factors affecting the use of maternal health services in Madhya Pradesh state of India: a multilevel analysis. Int J Equity Health. 2011;10(59):1-11.

20. Mumbare SS, Rege R. Ante natal care services utilization, delivery practices and factors affecting them in tribal area of north Maharashtra. Indian J Community Med. 2011;36(4):287-90.

21. Madore J, Rosenberg k, Dreisbach, Weintraub R. Positive outlier: health outcomes in Kerala, India over time. Cases in global health delivery. 2018. https://www.globalhealthdelivery.org/files/ghd/files/ghd-042_kerala_as_a_positive_outlier_2018_09_05.pdf. Accessed 24 Sept 2020.

22. NITI Aayog. Infant mortality rate (IMR) (per 1000 live births). Government of India. http://niti.gov.in/content/infant-mortality-rate-imr1000-live-births. Accessed 24 Sept 2020.

23. Haseena VA. Degradation in health status of tribal women in Kerala with reference to Attappady tribal block. J Cult Soc Dev. 2016;25:29-37.

24. United Nations. Millennium development goals and beyond 2015. https://www.un.org/millenniumgoals/bkgd.shtml. Accessed Sept 1 2014.

25. International Institute for Population Sciences (Deemed University). National Family Health Survey (NFHS-4), India, 2015-16: Kerala. Mumbai, India: International Institute for Population Sciences; 2018.

26. Bailey RL, West KP Jr, Black RE. The epidemiology of global micronutrient deficiencies. Ann NutrMetab. 2015;66(Suppl 2):22-3.

27. Daru JZJ, Fernández-Félix BM, Vogel J, Oladapo OT, Morisaki N, et al. Risk of maternal mortality in women with severe anaemia during pregnancy and post partum: a multilevel analysis. Lancet Global Health. 2018;6(5):e548-54.

28. Viteri FEGH. Adverse outcomes of poor micronutrient status in childhood and adolescence. Nutr Rev. 2002;60(5 Pt 2):S77-83.

29. World Bank. Kerala_-gender (English). India state briefs. Washington, D.C.: World Bank Group; 2017.

30. World Health Organization. WHO recommendations on antenatal care for a positive pregnancy experience. Switzerland: World Health Organisation; 2016.

31. Montoya A, Calvert C, Filippi V. Explaining differences in maternal mortality levels in sub-Saharan African hospitals: a systematic review and meta-analysis. Int Health. 2014;6(1):12-22. https://doi.org/10.1093/inthealth/iht037.

32. UNFPA. Pulled: tapping into the power of midwives to reduce maternal mortality in Guatemala. 2016. http://lac.unfpa.org/en/news/tappi ng-power-midwives-reduce-maternal-mortalityguatemala. Accessed 29 Nov 2020.

33. World Health Organization. Consultation on improving measurement of the quality of maternal, newborn and child care in health facilities. Geneva: World Health Organization; 2014. http://apps.who.int/iris/bitstream/10665/128206/1/9789241507417_eng.pdf. Accessed 29 Nov 2020.

34. International Institute for Population Sciences (Deemed University). District level household and facility survey-4: state Fact Sheet Kerala (2012-13). Mumbai, India: Ministry of Health and Family Welfare, Government of India; 2014. http://rchiips.org/pdf/dlhs4/report/KE.pdf. Accessed 24 Apr 2019.

35. Swaroop Y, Jha MK, Pandey SS, Singh V, Harendra. Handbook on social welfare statistics. Government of India, Ministry of Social Justice and Empowerment. p. 278-80. http://socialjustice.nic.in/writereaddata/UploadFile/HANDBOOKSocialWelfareStatistice2018.pdf. Accessed 29 Aug 2020.

36. Liu L, Chu Y, Oza S, et al. National, regional, and state-level all-cause and cause-specific under-5 mortality in India in 2000-15: a systematic analysis with implications for the sustainable development goals. Lancet Global Health. 2019;7(6):E721-34. https://doi.org/10.1016/S2214 -109X(19)30080-4.

37. Rasheeja T, Krishnan C. Empowering women through higher education: the Kerala episode. Issues Ideas Educ. 2013;1(2):221-9. 
38. Saleem M, Burdett T, Heaslip V. Health and social impacts of open defecation on women: a systematic review. BMC Public Health. 2019;19(158):1-12.

39. Jadhav A, Weitzman A, Smith-Greenaway E. Household sanitation facilities and women's risk of non-partner sexual violence in India. BMC Public Health. 2016;16(1139):1-10.

40. World Health Organization. Overcrowding: general considerations. Geneva:World Health Organization. https://www.who.int/ceh/indic ators/overcrowding.pdf.

41. Arimah BC. Slums as expressions of social exclusion: explaining the prevalence of slums in African countries. In: (UN-HABITAT) UNHSP, editor. Nairobi, Kenya; 2015. p. 26.

42. United Nations Human Settlements Programme (UN-HABITAT). Guide to monitoring target 11: improving the lives of 100 million slum dwellers: progress towards the millennium development goals. Nairobi: United Nations; 2003.

43. Scheduled Tribes Development Department. Healthcare schemes. http://www.stdd.kerala.gov.in/healthcare-schemes. Accessed 20 July 2020.

44. Scheduled Tribes Development Department. Education schemes. http://www.stdd.kerala.gov.in/education. Accessed 20 July 2020.

45. Schultz R. Closing the gap and the sustainable development goals: listening to Aboriginal and Torres Strait Islander people. Aust N Z J Public Health. 2020;44:11-3. https://doi.org/10.1111/1753-6405.12958.

46. Askew DA, Brady K, Mukandi B, et al. Closing the gap between rhetoric and practice in strengths-based approaches to indigenous public health: a qualitative study. Aust N Z J Public Health. 2020;44:102-5. https://doi.org/10.1111/1753-6405.12953.

47. Priyadarshini P, Abilash PC. Promoting tribal communities and indigenous knowledge as potential solutions for the sustainable development of India. Environ Dev. 2019;32(100459):1-12.

48. Byrne A, Morgan A. How the integration of traditional birth attendants with formal health systems can increase skilled birth attendance. Int J GynaecolObstet. 2011;115(2):127-34. https://doi.org/10.1016/j.ijgo.2011.06.019.

49. Randive B, Diwan V, De Costa A. India's conditional cash transfer programme (the JSY) to promote institutional birth: is there an association between institutional birth proportion and maternal mortality? PLoS ONE. 2013;8(6):e67452.

50. Contractor SQ, Das A, Dasgupta J, et al. Beyond the template: the needs of tribal women and their experiences with maternity services in Odisha, India. Int J Equity Health. 2018;17:134. https://doi.org/10.1186/s12939-018-0850-9.

51. UNICEF. Maternal and newborn health. http://www.unicef.org/esaro/5479_maternal_newborn_health.html. Accessed 24 Sept 2020.

52. Macdonald K. Indigenous peoples and development goals: a global snapshot. In: Hall G, Patrinos HA, editors. Indigenous peoples, poverty, and development. New York: Cambridge University Press; 2012.

53. Kudumbashree (State Poverty Eradication Mission). Attappady Comprehensive Tribal Development and Particularly Vulnerable Tribal Group Development Project: exclusive Adivasi women's collectives for regenerating agriculture for food and nutritional security, economic sustainability and self-reliance. Thiruvananthapuram: Government of Kerala. http://www.kudumbashree.org/storage/files/ff3en_attap pady-comprehensive-tribal-development-project.pdf.

54. Garcia-Casal M, Peña-Rosas J, De-Regil L, Gwirtz J, Pasricha S. Fortification of maize flour with iron for controlling anaemia and iron deficiency in populations. Cochrane Database of Syst Rev. 2018;12:CD010187.

55. Scheduled Tribes Development Department. Millet Village. http://www.stdd.kerala.gov.in/millet-village. Accessed 30 Nov 2020.

56. Pedley S, Pond K, Joyce E. Interventions for water provisions. In: Valuing water, valuing livelihoods. London: World Health Organization, IWA Publishing; 2011.

57. Epstein MJ YK. Redefining education in the developing world. Stanford Social Innovation Review. 2012. p. 19-20.

58. United Nations Department of Economic and Social Affairs. State of the world's indigenous peoples: indigenous peoples' access to health services. 2016. https://www.un.org/development/desa/indigenouspeoples/wp-content/uploads/sites/19/2018/03/The-State-of-TheWorlds-Indigenous-Peoples-WEB.pdf. Accessed 16 Sept 2020.

59. Shaji KA. With no proper road in Attappady, relatives carry pregnant tribal woman in makeshift stretcher. In: The Hindu. 2018. https:// www.thehindu.com/news/national/kerala/another-episode-of-deprivation-from-attappady/article24096349.ece. Accessed 30 May 2020.

60. Hall G, Patrinos HA. Indigenous peoples, poverty, and development. New York: Cambridge University Press; 2012.

61. Avendano R, Culey C, Balitrand C. Chapter 5: Data and diagnostics to leave no one behind. In: OECD. Development co-operation report 2018: joining forces to leave no one behind. Paris: OECD Publishing; 2018. p. 143-56. https://doi.org/10.1787/dcr-2018-en.

Publisher's Note Springer Nature remains neutral with regard to jurisdictional claims in published maps and institutional affiliations. 